\title{
THE RELATIONSHIP BETWEEN DENTAL HEALTH PERCEPTION AND DENTAL SERVICE UTILIZATION AMONG SCHOOL CHILDREN IN SOUTH JAKARTA
}

\author{
Paulus Januar*, Yufitri Mayasari*, Mutiara Rina Rahmawati Ruslan* \\ *Dental public health department, Faculty of dentistry, Universitas Prof. Dr. Moestopo (Beragama), Jakarta \\ Korespondensi: paulusjanuar@dsn.moestopo.ac.id
}

\begin{abstract}
ABSTRAK
Latar belakang: utilisasi pelayanan kesehatan gigimerupakan faktor penting dalam kesehatangigi. Utilisasi pelayanan kesehatan gigi dipengaruhi persepsi dan pandangan pentingnya kesehatan gigi. Tujuan: penelitian ini bertujuan untuk menganalisis hubungan antara persepsi mengenai kesehatan gigi dengan utilisasi pelayanan kesehatan gigi. Metode: Penelitian kualitatif potong lintang dilakukan pada 120 siswa dari 12 SD di Jakarta Selatan. Kuesioner digunakan untuk mendapatkan datamengenai persepsi kesehatan gigi dan utilisasi pelayanan kesehatan gigi. Hasil: sebagian besar siswa memandang kesehatan giginya baik dan tidak pernah sakit gigi. Hampir separuh sampel tidak pernah menggunakan pelayanan kesehatan gigi, dan yang menggunakan terutama untuk pencabutan dan penambalan gigi. Uji chi square menunjukkan perbedaan signifikan antara persepsi mengenai terjadinya sakit gigi dengan frekuensi dan pola utilisasi, dan tidak terdapat perbedaan yang signifikan antara persepsi mengenai kesehatan jaringan gigi dan kesehatan jaringan lunak mulut dengan frekuensi dan pola utilisasi pelayanan kesehatan gigi. Kesimpulan: terdapat hubungan antara persepsi mengenai terjadinya sakit gigi dengan frekuensi dan pola utilisasi. Tidak terdapat hubungan antara persepsi mengenai kesehatan gigi dan jaringan lunak mulut dengan utilisasi pelayanan kesehatan gigi.
\end{abstract}

Kata kunci: Persepsi, Utilisasi Pelayanan Kesehatan Gigi

\begin{abstract}
Background: the utilization of dental service is an important factor inoral health. The utilization of dental service is affected by the perception and the importance that the person gives to their oral health and needs. The objective of the study was to analyze the relationship between the perception of dental health and utilization of dental service. Method: a qualitative analytical cross-sectional study was conducted among 120 students of 12 elementary schools in south Jakarta, selected using a proportional sampling method. A questionnaire was administered to elicit data on dental health perception and dental service utilization. Result: Most students perceived their dental health as good and never had dental sickness. Almost half of the sample never utilized dental service and the utilization of dental service mostly for extracting and filling the teeth. Chi-square test showed significant difference between the perception of the occurrence of dental sickness with the frequency and pattern of dental service utilization and no significant difference between the perception of the health of teeth and oral soft tissue with the utilization of dental service. Conclusions: there were relationships between the perception of the occurrence of dental sickness with the frequency and with the pattern of dental service utilization. There was no relationship between the perception of the healthy teeth and oral soft tissue with the utilization of dental service.
\end{abstract}

Keywords: perception, utilization of dental service

\section{BACKGROUND}

$\mathrm{D}$ ental service utilization research is toimprove health outcomes of individuals and societyat large.The utilization of dental service is an important factor of oral health of individual and society as well. ${ }^{1}$ The exposure to dental services in early childhoodcan play an importantrole in encouraging dental health awareness and early preventivevisits to dental care.There are many evidences to support that early dental service utilization is cost-effective and can improve dental healthrelatedquality of life. ${ }^{2}$

Health service utilization is the use of health services for the purpose of preventing diseases, and curing health problems, promoting maintenance of health and well-being, or obtaining information about one's health status and prognosis. The measurement 
of utilization is often reported as the percentage of persons who use a certain service over individuals eligible for that service in a period of time. ${ }^{3}$

Researchers have long been fascinated by the factors that prompt individuals to use medical and dental treatment. Many factors have been studied by various researchers that conducted many studies in various social settings, ages, and occupations. Derived from the studies, these factors include but are not limited to culture, social class, age, gender, belief in efficacy, access to and knowledge of health care. It is assumed that there are still many factors should be investigated in order to find out the factors that influenced the utilization of health and dental service. From psychological perspective, the utilization of health services outlines several factors that play an instrumental role in determining health and illness behaviors. These include, perception of health and how severe the symptoms are, and the knowledge and cultural perception of the health and illness in daily life and in communal setting as well. The availability and accessibility to dental service also play an important role in utilization of dental service. These factors also include the extent to which the illness disrupts everyday life and whether responding to the illness would prevent the fulfillment of other needs. ${ }^{4,5}$

A review of the studies in North America and Latin America showed that the predictors of dental health service utilization of the children were factors that related to children or adolescents (age, gender, frequency of tooth brushing, and chronic diseases), perception of oral health, perceived oral health needs, dentists and dental services availability, and follow-up programs of oral health services. The studies of this review reported that demographic, socioeconomic, parental, behavioral and contextual factors as well as those related to the dentist and to the oral and/ or systemic health status were associated with the utilization of dental health service by the pediatric population between 0 and 15 years old. Thus it is very important to incorporate those factors besides the oral physical conditions in the planning of dental service program to make it a comprehensive one. ${ }^{5}$

The utilization of dental service is affected by several factors in the level of individual, family, and also in the level of community. Rocha et al. based on their study among school children in Brazil, concluded that the utilization of dental service is affected by perceptions and the importance that a person gives to their oral health, and in a more comprehensive approach not only by their need for treatment that based on clinical judgment. Therefore, in addition to the quantitative data of a disease (clinical signs), it is also very important to analyze the qualitative data, that is, to not only know the clinical condition, but also how the individual perceives him/herself, as well as his/her conception regarding oral health, and also social and cultural background. ${ }^{6}$
The perception is subjective, combining physical components and emotional wellness, being influenced by behaviors related to health care and also social and environmental factors as well. The clinical situation only takes the opinion of the professional into account and ignores of the understanding the perception of the individual. Therefore it is important also the understanding of the perception of the individual concerning his or her dental health and also perception concerning on dental service utilization. Yet the use of measures that assess how a person thinks about his/her health is valuable, such as self-perception. When the patient is motivated and aware of their own condition and also their needs for dental service, there is an interest to take care of their oral health and thus it is also a means to make an improvement to their quality of life. Dental public health programs that are planned and assessed based only on the clinical factors may have gathered incomplete information for the individual seeking care. So it is important to understand self-perceived oral health that comprised of the perception of the teeth and also the oral enviroment. ${ }^{6}$

Clinical indicators can be used to measure the population's health, however, the use of subjective indicators by means of self-perception, encompassing psychological and social aspects, adds new understanding of how diseases affect the individual as a whole. Thus clinical indicators alone usually are not very satisfactory in assessing a patient because dental treatment not only concerning physical entities, but also the mental and social well-being of a patient. The investigation into oral health self-perception is fundamental to the planning of health promotion and education actions that can result in improvements to the population's quality of life. ${ }^{7}$ The objective of the study was to analyze the relationship between perceived dental health and utilization of dental service among school children in South Jakarta.

\section{METHODS}

The design of the study was a quantitative, analytical, cross-sectional survey. The samples were 120 students from 12 elementary schools in South Jakarta. The samples were selected using proportional sampling method according to the criteria of inclusion and exclusion as well.

The data on dental perception and utilization of dental care were gathered using an interview-based questionnaire. The questionnaire was in two parts viz. 1The perceptions of dental health and 2 The utilization of dental care.

The perception of dental health comprised of perception of the health of the teeth, perception of the health of oral soft tissue, and perception of the occurrence of dental sickness. The perception of the health of the teeth and the oral soft tissue was 
classified as good, bad, and do not know respectively. The perception of the occurrence of dental sickness was classified as often, sometimes, rare, and never.

The utilization of dental service was measured by the frequency and the pattern of dental visits. The frequency ofdental service utilizationwas classified as regular (every year), irregular (occasionally), episodic (as needed),or no use (never).Thepattern of the dental service utilizationwas the reason for last dental visit. The pattern of the dental service utilization based on the answers of the school children and through dental records if possible. The pattern of the dental service utilization was classified as extraction, filling, periodic dental checkup, others, and never.

The data were entered, cleaned, stored, and analyzed using computer statistical software in the Department of Dental public Health of Faculty of Dentistry of Prof DR Moestopo University in south Jakarta Indonesia. Bivariate statistic analyses were used to determine the relationship between dental health perception and dental care utilization. Chisquare test was applied as a bivariate analysis for statistical significance testing, and $\mathrm{p}<0.05$ was considered statisticallysignificant.

All parents or guardian of participatingchildren consented to participationin the study. The consents of the parents of the school children derived through written form and they are informed before head. Atthe schools included in the study, permission was also sought from headmasters and teachers.

\section{RESULTS}

The samples were 120 children from 12 elementary schools in South Jakarta. The sample aged was 6 to 12 years old, and the mean age was 9.19 years old. Based on gender, the samples comprised of equal proportion viz. 59 male and 61 female students. The selection of the samples using proportional sampling method among the students that fulfilled the inclusion and exclusion criteria.

Table 1 showed the perception of dental health among elementary school children. The results of the perception of dental health in table 1 showed that most of the students perceived the health of their teeth were good $(75.8 \%)$, and the rest answered as bad $(14.2 \%)$, and did not know $(10.0 \%)$. Most of the students also perceived the health of oral soft tissues were good $(70.8 \%)$, and the rest answered as bad (13.3\%), and did not know (15.8\%). Based on their perceptions of the occurrence of dental sickness, showed that most of the students answered that they never had dental sickness $(39.2 \%)$, and the rest answered as rare $(21.7 \%)$, often $(20.8 \%)$, and sometimes $(20.8 \%)$.
Table 1. Perception of Dental Health

\begin{tabular}{cc}
\hline PERCEPTION & $\begin{array}{c}\text { FREQUENCY } \\
\text { n (\%) }\end{array}$ \\
\hline $\begin{array}{c}\text { Perception of The Health of The } \\
\text { Teeth }\end{array}$ \\
Good & $91(75.8 \%)$ \\
Bad & $17(14.2 \%)$ \\
Did not know & $12(10.0 \%)$ \\
TOTAL & $120(100 \%)$ \\
\hline Perception of The Health of The & \\
Oral Soft Tissue & \\
Good & $85(70.8 \%)$ \\
Bad & $16(13.3 \%)$ \\
Did not know & $19(15.8 \%)$ \\
TOTAL & $120(100 \%)$ \\
\hline Perception of The Occurrence of & \\
Dental Sickness & \\
Often & $25(20.8 \%)$ \\
Sometimes & $22(18.3 \%)$ \\
Rare & $26(21.7 \%)$ \\
Never & $47(39.2 \%)$ \\
TOTAL & $120(100 \%)$ \\
\hline
\end{tabular}

Table 2 showed the frequency and pattern of dental service among the students. The data of the frequency of utilization of dental service on table 2 showed, there were $65(54.2 \%)$ students reported ever utilized dental service with various frequency of dental visit, comprised of $8(6.7 \%)$ students regularly every year, $16(13.3 \%)$ students irregular/occasionally, and $41(34.2 \%)$ students visited dental service as needed. There were $55(45.8 \%)$ students answered that they never utilized dental service.

The data of the pattern of dental service utilization were gathered by questioning to the school children who had ever utilized dental service. The school children who had ever utilized dental service, then wereasked to indicate whether their visits had been for extraction, filling, periodic dental checkup, and others. Based on their answers to the questionnaire, out of $65(54.2 \%)$ children that ever utilized dental service, $28(23.3 \%)$ of them needed teeth extracted, $21(17.5 \%)$ of them needed teeth filled, and only $9(7.5 \%)$ of them utilized dental service for periodic check up.

Based on the data in table 1 and table 2, Chi-Square statistics test was used to analyze the relationship of the perception with the dental service utilization. The perception of dental health comprised of perception of the health of the teeth, perception of the health of oral soft tissue, and perception of the occurrence of dental sickness. The utilization of dental service was measured by the frequency of dental visit, and the pattern of dental visits. 
Table 2. Dental Service Utilization

\begin{tabular}{cc}
\hline DENTAL SERVICE & FREQUENCY \\
UTILIZATION & $\mathbf{n}(\%)$ \\
\hline Frequency of Dental Service & \\
Utilization & $8(6.7 \%)$ \\
Regular /every year & $16(13.3 \%)$ \\
Irregular /occasionally & $41(34.2 \%)$ \\
Episodic /as needed & $55(45.8 \%)$ \\
No use /never & $120(100 \%)$ \\
TOTAL & \\
Pattern of Dental Service & \\
Utilization & $28(23.3 \%)$ \\
Extraction & $21(17.5 \%)$ \\
Filling & $9(7.5 \%)$ \\
Periodic dental checkup & $7(5.8 \%)$ \\
Others & $55(45.8 \%)$ \\
Never & $120(100 \%)$ \\
TOTAL &
\end{tabular}

The perception of the health of the teethshowed no significant difference by the frequency of dental service utilization $\left(\mathrm{X}^{2}=2.925, \mathrm{p}=0.818\right)$, and also the perception of the health of the teeth showed no significant difference by the pattern of dental service utilization $\left(\mathrm{X}^{2}=9.201, \mathrm{p}=0.325\right)$. The perception of the health of oral soft tissue showed no significant difference by the frequency of dental service utilization $\left(\mathrm{X}^{2}=0.394, \mathrm{p}=0.999\right)$, and also perception of the health of oral soft tissue showed no significant difference by the pattern of dental service utilization $\left(X^{2}=4.174\right.$, $p=0.841)$. These results indicated that there was no significant relationship between the perceptions of the health of the teeth with the frequency and pattern of dental service utilization, and also there was no significant relationship between the perception of the health of oral soft tissue with the frequency and pattern of dental service utilization.

The perceptions of the occurrence of dental sickness showed significant difference by the frequency of dental service utilization $\left(\mathrm{X}^{2}=28.555\right.$, $\mathrm{p}=0.001$, and also the perceptions of the occurrence of dental sickness showed significant difference by the pattern of dental service utilization $\left(\mathrm{X}^{2}=40.513\right.$, $p=0.000)$. These results indicated that there was a relationship between the perceptions of the occurrence of dental sickness with the frequency of dental service utilization and also there was a relationship between the perceptions of the occurrence of dental sickness with the pattern of dental care utilization.

\section{DISCUSSION}

The aim of this study was to examine the relationship between perceived dental health and utilization of dental service among school children in south Jakarta - Indonesia. Based on the results of this study, the perception on dental health could improve our understanding of how the children perceived their health conditions and expectations of treatment. In addition, the present study could provide supporting data that help to create health strategies and programs for the improvement of dental health as an integral part of the complete health of the whole body.

Perception of dental health could be a motivatorto the utilization of dental service. The results of this study showed that only the perception of the occurrence of dental sickness that influenced the utilization of dental service. The results of this study showed that the utilization of dental service was associated with the extent of awareness about dental diseases. The results of this study indicated that the reason for the utilization of dental service was more emphasized on curative measures than on preventive ones.

The results of the study showed that both the perception of the health of the teeth and the health of oral soft tissue did not associate with the utilization of dental service. From the facts that the perception of healthy teeth and healthy oral tissue did not associate with the utilization of dental service, it seemed that the children in this research did not pay much attention to preventive care. Thus the recommendations from this study address to further efforts to increase dental health awareness among school children especially more on preventive care.

Dental diseases are preventable, hence prevention should be the first priority of dental service as a part of dental program for individual and toward the community. To provide preventive care and earlytreatment, there is a need for a greater awareness of dental service utilization. Increased exposure to dental health education and to early childhoodin dental service may be helpful. Inthe meantime, primarycare providers can play an importantrole in encouraging early preventivevisits to a dental professional. ${ }^{2}$

The results of the present study revealed that most school children perceived the condition of their teeth and oral soft tissue were good but it was not associated with regular visit to the dentist. Usually the students seek dental treatment only when there was a complaint to their dental health. Therefore the perception of good dental health did not influence the utilization of dental care. On the contrary, the perception of poor oral health status associated with the utilization of dental service. From this situation it was not a strong basis for the improvement of their dental health, even it was not conducive for maintaining their dental health. Most of the samples perceived that dental service was for curing dental diseases, and not for the prevention of dental diseases.

Perception of dental health is a multidimensional construct that includes psychological,psychosocial and functional aspects. The construct includes dental and oral disease, functional oral capacity, pain, aesthetics, also psychologicaland psychosocial components. 
Self-reported on perception of oralhealth status is a relatively simple and easy method of assessment, which can be routinely collected and has severaluses, such as the assessment of perceived treatment needs, and as a monitoring tool for oral health intervention.Although most studies on oral healthperception carried out on adult populations, there had beensome studies performed on children and adolescentswhich had shown good consistency on self-rated oral health. ${ }^{9}$ Therefore this study was conducted among elementary school children to access the association between their perception of dental health with their utilization on dental service.

The results of this study could be compared with previous studies done by Rocha et al. ${ }^{6}$ in Brazil that concluded, the behavioral factor of routine trip to the dentist, was associated with the extent of perception about dental diseases. The lack of routine visits to the dentist increased the chances of the individual to perceive poorer oral health. Moreover, according to that study, the characteristics, attitudes and parental perceptions also influenced the use of dental services for children, because children depend on their parents to visit the dentist. ${ }^{6}$ In this study the perception of the parents or caregivers and also their influences were not concluded. It should be concluded for further study among elementary school children in south Jakarta.

The results of this study showed that the perception of the occurrence of dental disease influence the utilization of dental service. The perception of the health of the teeth and the soft tissue showed no significant relationship with the frequency and the pattern of dental service utilization. According to Maida et al. in their study, came to the conclusion that identifying a link between oral health status and perception of oral health reported by individuals was an important finding. The results of the present study among elementary school children in south Jakarta was in accordance with the study of Maida et al (2015) that reported an association between subjective perception of dental diseases with socioeconomic factors and clinical attendance for oral health care. Maida, et al conducted focus groups from five dental practices in Los Angeles County, three in the East San Fernando Valley (low-income communities) and two in the West San Fernando Valley (affluent communities) with ethnically, socioeconomically, and geographically diverse youth (8-12, 13-17 years) to identify perceptions of oral health status. ${ }^{10}$

The present study showed that the students mainly utilized oral health facility for symptomatic reasons. The results of this study showed that, most of school children were episodic or as needed $(34.2 \%)$, and never $(45.8 \%)$ to utilize dental service. Episodic and no utilization of dental servicewere considered signs of inadequateutilization and indicate that barriers toaccess dental service exist. Episodic utilization of dental service only as needed were usually prompted by a dental conditionthat was caused by an acute problem, and such episodic visitshindered preventive treatment as wellas early diagnosis and prompt treatment. On the pattern of dental service utilization, our data demonstrated that the proportion of extraction $(23.3 \%)$ and filling (17.5\%) was much greater than periodic checkup (7.5\%). The extraction as the highest proportion of dental service utilization indicated that the school children usually visited the dentist already in severe or very severe conditions, and then for the dentist there was no other choice anymore and the teeth had to be extracted, as the only prompt treatment.

In this study, low and infrequentutilization of dental service appeared to affectchildren's oral health status. Darmawikarta et al studied factors associated with dental care utilization in early childhood in Canada. The study showed that barriersto utilization of dental care among low-incomefamilies may include financial cost, accessto transportation, school absencepolicies, and a belief that dental healthmay not be important to overall wellbeing. As the consequences of low utilization of dental service, the dental and oral condition of the children were in bad condition. ${ }^{2}$

Proper utilization of dental service is essential in promoting and maintaining dental health of individuals, and also in promoting and maintaining oral health of the community as well. Beside dental health promotion and prevention of dental diseases in the community and in individual basis, the utilization of dental service is also very important to be a comprehensive dental health program to the community. This implies that routine dental visit is an indispensable element in the attainment and sustenance of good oral health. It should be that theperception of maintaining oral health influences their utilization of dental care. But on the contrary, Eigbobo and Obiajunwa based on their study in Nigeria concluded that the utilization of dental services among school children was low and the major barrier to utilization of dental service was no perception of dental treatment need. ${ }^{11}$ The results of this study also showed no relationship between good perceptions of dental health with the utilization of dental service. It meant that the perceptions of good dental health did not affect the children in utilizing dental service for fulfilling their real needs in dental care to preserve their dental health.

Limitations of this study, the use of questionnairemight be subjected to recall bias. The data from the self-reported survey were clearly based on the testimony of the samples. Moreover the study was a cross-sectional survey, therefore it was difficult to conclude a causal relationship among the variables observed. Longitudinal studies should be conducted to minimize bias and to clarify of causality. Therefore further study on a well monitored cohort basis of 
elementary school children would be a better one for the accuracy of the data and especially in concluding a causal relationship.

This study carried out among school children in South Jakarta, therefore further study was needed with the samples of various populations and investigates more other factors that might influence the utilization of dental service. Further study is needed because the understanding why people utilize health service is central in increasing health care utilization and efficacy, and therefore also as a means in enhancing oral health of the community. Based on the understanding of the factors that affect health care utilization, it can assist in creating effective health campaigns, policies, and promotion programs.

\section{CONCLUSIONS AND RECOMMENDATIONS}

From this study, it was concluded that the perception of occurrence of dental sickness had been shown to affect the frequency and the pattern of dental service utilization among elementary school children in South Jakarta. The study also showed that the perception of good dental healthdid not necessarily affect the frequency and the pattern of dental service utilization. Based on the finding of this study that the utilization of dental service mostly when the children had already dental sickness, it was imperative to improve the awareness for the utilization of dental service especially for preventive measures among elementary school children in South Jakarta. Further research is essential to adequately understand more factors that affect the utilization of dental care service among elementary school children, particularly in South Jakarta.

\section{REFERENCES}

1. Kim, C.S., Han, S.Y., Lee, S.E., Kang, J.H., Kim, C.W. Dental Care Utilization for Examination and Regional Deprivation. J Prev Med Public Health. 2015;48:195-202.

2. Darmawikarta, D., Chen, Y., Carsley, S., Birken, C.S., Parkin, P.C., Schroth, R.J., and Maguire, J.L. Factors Associated With Dental Care Utilization in Early Childhood.Pediatrics. 2015;133;e1594
3. Nasseh K, Vujicic M. Dental care utilization rate continues to increase among children, holds steady among workingage adults and the elderly. Health Policy Institute Research Brief. American Dental Association. October 2015.Available from:http://www.ada.org/ / Media/ADA/Science\%20and\%20Research/HPI/Files/ HPIBrief_1015_1.ashx/.Accessed June 15, 2017.

4. Essays, U.K. Theories Of Health Care Utilization Health And Social Care Essay. Available from:https://www. uniassignment.com/essay-samples/health-social-care/ theories-of-health-care-utilization-health-and-socialcare-essay.php?vref=1, accessed may, 25, 2019.

5. Curi, D.S.C., Figueiredo, A.C.L., Jamelli, S.R. Factors associated with the utilization of dental health services by the pediatric population: an integrative review. Ciência \& Saúde Coletiva, 2018 ; 23(5):1561-1576.

6. Rocha, N.B., Moimaz, S.A.S, Garbin, A.J.I, Salibam O., Garbin, C.A.S. Relationship between Perception of Oral Health, Clinical Conditions and Socio-Behavioral Factors of Mother-Child.Brazilian Research in Pediatric Dentistry and Integrated Clinic .2015, 15(1):113-121.

7. Rodrigues, F., Reboucas, A.G., Florio, F.M.Selfperception of oral health among schoolchildren in a city of Amazonas, Brazil: related factors. RGO, Rev Gaúch Odontol, Porto Alegre, v.65, n.1, p. 44-51, jan./mar., 2017.

8. Maida, C.A., Marcus, M., Hays, R.D., Coulter, A.D., Spolsky, V.W. Child and Adolescent Perceptions of Oral Health Over the Life Course.Qual Life Res. 2015 ; 24(11): 2739-2751.

9. Banu, A., Şerban, C., Pricop, M., Urechescu, H., and Vlaicu, B. Dental health between self-perception,clinical evaluation and body imagedissatisfaction - a crosssectional study inmixed dentition pre-pubertal children. BMC Oral Health . $2018 ; 18: 74$.

10. Maida, C.A., Marcus, M., Hays, R.D., Coulter, A.D., Spolsky, V.W. Child and Adolescent Perceptions of Oral Health Over the Life Course.Qual Life Res. 2015; 24(11): 2739-2751.

11. Eigbobo J.O., Obiajunwa C.C. Utilization of dental services among secondary school students in Port Harcourt, Nigeria. Eur J Gen Dent .2016; 5: 74-9. 